\title{
Work environment and accreditation: analysis by mixed explanatory sequential methoda
}

\author{
Ambiente de trabalho e acreditação: análise pelo método misto explanatório sequencial \\ Ambiente de trabajo y acreditación: análisis por el método mixto explanatório secuencial
}

João Lucas Campos de Oliveira ${ }^{1}$ (B)

Verusca Soares de Souza² ${ }^{2}$ Ana Carolina Simões Pereira ${ }^{2}$ (iD Maria do Carmo Fernandez Lourenço $\operatorname{Haddad}^{3}$ (D) Sonia Silva Marcon² (D) Laura Misue Matsuda ${ }^{2}$ (D)

1. Universidade Federal de Mato Grosso. Cuiabá, MT, Brasil.

2. Universidade Estadual de Maringá Maringá, PR, Brasil.

3. Universidade Estadual de Londrina. Londrina, PR, Brasil.
Corresponding author:

João Lucas Campos de Oliveira

E-mail: enfjoaolcampos@yahoo.com.br

Submitted on $12 / 02 / 2017$.

Accepted on 08/03/2018.

DOI: 10.1590/2177-9465-EAN-2017-0379

\section{Abstract}

Objective: To analyze the - possible - interference of Accreditation in the work environment of the nursing team. Method: Mixed explanatory sequential method study. The first (preponderant) quantitative phase of the research was the application of the Brazilian version of Nursing Work Index Revised (B-NWI-R) to a representative sample $(n=226)$ of nursing workers from three hospitals, one of them being certificate of excellence by national Accreditation and two unsealed hospitals. After descriptive analysis of the data, it was possible to connect the information, which culminated in the data collection, through interviews $(n=39)$, of the second (qualitative) stage of the mixed research. The final analysis included the application of inferential statistics and qualitative analysis by the Collective Subject Discourse (DSC), connected in the B-NWI-R dimensions. Results: There was no statistically significant association in the comparisons. However, the results presented better in the certified hospital, ratifying the DSC of this institution. Conclusion: Accreditation did not significantly interfere with nursing staff perception of the work environment.

Keywords: Hospital Accreditation; Working Environment; Nursing, Team; Quality Management; Intensive Care Units.

\section{RESUMO}

Objetivo: Analisar as - possíveis - interferências da Acreditação no ambiente de trabalho da equipe de enfermagem. Método: Estudo de método misto explanatório sequencial. A primeira fase (preponderante) quantitativa da pesquisa ocorreu pela aplicação da versão brasileira do Nursing Work Index - Revised (B-NWI-R) a uma amostra representativa $(\mathrm{n}=226)$ de trabalhadores de enfermagem de três hospitais, sendo um deles certificado em nível de excelência pela Acreditação nacional e dois hospitais não selados. Após análise descritiva dos dados, viabilizou-se a conexão das informações, que culminou na coleta de dados, por entrevistas ( $n=39$ ), da segunda etapa (qualitativa) da pesquisa mista. A análise final compreendeu a aplicação de estatística inferencial e a análise qualitativa pelo Discurso do Sujeito Coletivo (DSC), conectada nas dimensões do B-NWI-R. Resultados Não houve associação estatística significativa nas comparações. Porém, os resultados se apresentaram melhores no hospita certificado, ratificando o DSC desta instituição. Conclusão: A Acreditação não interferiu significativamente na percepção da equipe de enfermagem sobre o ambiente de trabalho.

Palavras-chave: Acreditação Hospitalar; Ambiente de Trabalho; Equipe de Enfermagem; Gestão da Qualidade; Unidades de Terapia Intensiva.

\section{RESUMEN}

Objetivo: Analizar las - posibles - interferencias de la Acreditación en el ambiente de trabajo del equipo de enfermeira. Método: Estudio de método mixto explanatório secuencial. La primera fase (preponderante) cuantitativa de la investigación se dio por la aplicación de la versión brasileña del Nursing Work Index - Revised (B-NWI-R) a una muestra representante $(n=226)$ de trabajadores de enfermería de tres hospitales, siendo uno de ellos certificado por la institución Acreditación nacional a nivel de excelencia y dos hospitales no sellados. Después del análisis descriptivo de los datos, se viabilizó la conexión de las informaciones que culminó en la recolección de datos, por entrevistas $(n=39)$, de la segunda etapa (cualitativa) de la investigación mixta. E análisis final comprendió aplicación de estadística inferencial y análisis cualitativo por el Discurso del Sujeto Colectivo (DSC) conectada en las dimensiones del B-NWI-R. Resultados: No hubo asociación estadística significativa en las comparaciones. Sin embargo, los resultados se presentaron mejores en el hospital certificado, ratificando el DSC de esta institución. Conclusión: La Acreditación no interfirió significativamente en la percepción del equipo de enfermería sobre el ambiente de trabajo.

Palabras clave: Acreditación de Hospitales; Ambiente de Trabajo; Grupo de Enfermería; Gestión de la Calidad; Unidades de Cuidados Intensivos. 


\section{INTRODUCTION}

The work process in nursing, specially in hospitals, involve daily complex decisions and attitutes that are about the viabilization of care. Thus, it's evident the relevance of improvement of favorable envirornments to the execution of work actions in the nursing team, as well as the Professional perception about their own work, once such fact tends to reverberate in the produced care. ${ }^{1-4}$

There are findings that, the better the work environment for professional nursing practice at the technical level, the lower are the burnout rates, the intention to leave the job, and; the higher the level of job satisfaction. ${ }^{1}$ In addition, the work environment, evaluated positively by nursing workers, is related to: the approval of quality of care by professionals; the favorable trend in qualified and safe care measured by concrete measures such as indicators; and positive perception about patient safety attitudes. . $^{3,5,6}$

The interaction quality and safety in the care with the nursing staff's work envirornment have been highlighted around the world, due to relevance already acepted by the Institute Of Medicine $(\mathrm{IOM})^{7}$ that the labor environment influences the quality of care produced. This assumption reinforces the recent finding that there is a direct association between "poor" environments - or unfavorable to professional nursing practice and the increased risk of death among hospitalized patients in the United States of America. ${ }^{8}$

Quality of care as a direct or indirect product of the work envirornment in health and nursing, remits to the need to improve professional practice scenery based on management strategies. ${ }^{7-9}$ In this scope, Acreditation emerges as a management system that, in theory, is a systematic, strategic and directive means for systemic improvements in the quality of the health work product, which, within the overall understanding of Accreditation, also has repercussions on the environment of work of the member organizations..$^{10,11}$

Accreditation has well defined methods, which are disseminated to all organizational spheres, which are periodically evaluated in order to generate the mechanism of continuous and successful improvement, resulting in quality certification. ${ }^{10,11}$ Despite the possible competitive advantage derived from Accreditation certification, this system influences health work - more dynamic than the qualifying seal -, to the example of changes in the work process that are linked to the basic principles of strategic management for quality, such as the use of management improvement tools. ${ }^{12}$

It should be highlighted that research focused on the relationship between Accreditation and work environment perceived/evaluated by nursing is not unprecedented in Brazil. ${ }^{13}$ However, there is only an investigation of the scope of this study, which was carried out only in public hospitals in the state of São Paulo, and therefore it is counterproductive to attribute full knowledge of the relationship between Accreditation and work environment.
To explore the best or greatest knowledge about - possible interference of Accreditation in the work envirornment is relevant, specially in the brazilian context, where the system of management of quality, still in phase of expansion in the country had it's implantation in less than two decades. ${ }^{11}$ Therefore, studies with the enphasis in the impact knowledge or system influence of tariff management, in the different spheres of health work, can contribute to adjust it to its real purposes, strictly aligned with health quality, which undoubtedly includes the work environment perceived by nursing.

Once the inclination to investigate the problem is justified, it is questioned whether: is there interference of Accreditation in the perception of the nursing team about the work environment? Therefore, in order to answer this question, this study's aim was to analyze the - possible - interference of Accreditation in the work environment of the nursing team.

\section{METHOD}

Cross-sectional study based on the mixed method of sequential explanatory drawing. In this methodological design, mixing or combining data is enabled by the connection procedure, in which the data analysis is the first phase of the study - which has a higher weight and it's of quantitative approach (QUAN) - connects itself the data collection of qualitative step (Qual), which is the secondary phase on attribution of weight of this nature in a mix method study. ${ }^{14} \mathrm{~A}$ typical exemple of this modality of investigation is the employment of interviews to deepen findings of a survey research. ${ }^{15}$

The research happened on all Intensive Care Units (ICU) of three hospitals located in the countryside of Paraná, Brazil. The selection of fields answered to the following procedure: firstly, search on National Organization Accreditation (ONA)'s online page, selecting a certified hospital $(\mathrm{AH})$ in greater level (Accreditated with Excelence) by ONA's methodology. After $\mathrm{AH}$ 's selection, that it was private, a new search was made in the National Register of Health Establishments of two more hospitals, one of them private not certified (HB) and the third one, public, equally not endowed with Accreditation certification (HC).

Selection criteria for the places were: to be a general hospital located in Paraná state; to have beds for intensive care and, in the $\mathrm{AH}$ case, to have Accreditation certification for a longer time, disposed in ONA's eletronic site. Already in the cases of the places for comparison, were selected institutions not certified by the Accreditation; with the same size of $\mathrm{AH}$; distant in radius of maximum 150 kilometers; holders of ICU beds; and each one with a different characteristic of care, that is, a private hospital and another public. The latter procedure was employed to increase the variability of comparisons.

ICUs were delimited as sites of investigation in the three hospitals due to the lower chance of differences in the type of service provided and, therefore, reduction in the interference of comparability parameters. Already the maximum distance 
between the institutions was established to reduce the possibility of a wide cultural contrast in the work process of the nursing teams.

In the first phase of the study (QUAN), nursing professionals that worked in ICUs from the three services participated. To define the sample, at each site, a representative sample of finite populations was calculated, that is, on the total $(\mathrm{AH}=107 ; \mathrm{HB}$ $=80$; e $\mathrm{HC}=117$ ) of workers in the units, whose amount was requested to the nursing services of each organization. Stratified samples from each hospital were estimated based on $95 \%$ coverage and $5 \%$ error estimate.

In the stratified sampling, the segregation of professionals by hierarchical level (nurses and mid-level workers) was considered; and also in the stratification of ICUs in units for adult care (general or specialized - ICU-A) and child care sectors (pediatric and neonatal-ICU-I).

Once the stratified samples were dimensioned, the data collection of the first phase (QUAN) of the study took place between December 2016 and March 2017. In the collection, the nursing professionals of all ICUs and all shifts of the three hospitals. After the approach, it was verified if each participant met the criterion of inclusion of working in the sector for at least six months.

Respecting the eligibility, the worker was invited to participate in the study, at which point he explained about the purpose of the research and his form of driving. In case of acceptance, the participant signed the Term of Free and Informed Consent (TCLE), which was also signed in two ways of equal content by the researcher.

The collection of the first stage (QUAN) was carried out by the application of a form for sociodemographic and labor characterization of the participants. To evaluate the perception about the work environment, the Brazilian version of the Nursing Work Index - Revised (B-NWI-R) was used, which was validated in the national context between nurses and nursing technicians. ${ }^{16,1} \mathrm{First}$ step collection coleta happened until each stratified sample filling.

B-NWI-R is a measure scale in Likert format. In its employment, 15 items are staggered in four points of choice of agreement and are distributed in four subscales: Autonomy (five items); Relationship between doctors and nurses (three items); Control over the environment (seven items); and Organizational Support, with 10 items derived from the mentioned subscales. ${ }^{16}$

The autonomy subscale represents the freedom/power that the professional has to solve problems related to nursing care in his work environment, and control refers to how the professional controls the practices of nursing interest in the work. The subscale relationship between doctors and nurses refers to mutual professional respect between the working classes in question, aiming at better communication at work and the achievement of the common goal, ie, patient care. In turn, the organizational support subscale focuses on situations in which the organization (mainly represented by managers) supports nursing workers, so that they develop their professional practice. ${ }^{16}$
After the first phase of the survey (QUAN) was collected, a descriptive statistical analysis of the data was performed, using measures of central tendency, dispersion and proportion. This procedure enabled the connection provided in the mixed study of sequential explanatory design. ${ }^{14}$

Regarding the appreciation of the work environment measured by the B-NWI-R, the lower the scores on the items and subscales of the instrument, the better the perception about the work environment, which is more favorable to professional nursing practice. ${ }^{16}$ Therefore, the median $(2,5)$ was the evaluative cut-off point.

With the points of interest raised in the data connection, it was decided to sequence the data collection of the second phase (Qual), using all B-NWI-R domains/subscales, since there was similarity in the analysis between the sites surveyed. In this way, the "Qual" step was used to provide a more in-depth understanding of the statistical data of these domains in all hospitals, followed by a joint assessment of the "QUAN" and "Qual".

The sequenced data collection (Qual) was carried out in June 2017, with the participation of professionals from the same sectors and hospitals investigated, as long as they had participated in the first phase (QUAN). These participants were approached for convenience and, after acceptance, also formalized via the ICF, the qualitative data were collected through a focused interview, directly respecting the nuances evaluated by the B-NWI-R. The number of interviews was defined by the successive repetition of the participants' statements, in each hospital, separately.

The final analysis of the data was mediated by the interpretive junction of the inferential statistics and the qualitative analysis, and this product was sequenced from the primary descriptive understanding. For the quantitative analyzes, the tabulated data were treated in the software Statistical Package for Social Sciences, version 21 (SPSS-21). Before the analytical procedure itself, the data were normality by means of the KolmogorovSmirnov test.

Considering the refuted normality, the data were submitted to non-parametric inferential analyzes between two pairs of hospitals/populations, considering the factor "Accreditation" (AH $x \mathrm{HB} ; \mathrm{HA} \times \mathrm{HC}$ ) and also in the total analysis of the three groups. The Mann-Whitney test was used in the comparison of two groups and Kruskal-Wallis in the analysis of the three groups. In all inferential analyzes, statistical significance was considered at $5 \%$, when $p$-value $\leq 0.05$. In addition, the reliability of the B-NWI-R and its subscales was measured by Cronbach's Alpha, delimiting it when the value was $\geq 0.7 .{ }^{17}$ In case of valuation lower than the established point, there would be no data recollection; However, in the general analyzes of each hospital and the sample as a whole, reliability was confirmed.

The study's second phase (Qual) data were transcribed in full, in digital resource. Subsequently, the Collective Subject Discourse (DSC) was used as a means to group the evoked 
statements, and to describe the work environment perceived by nursing professionals as if each research site represented a "collective singularity". ${ }^{18}$

In this mixed study, the B-NWI-R domains were seized in the DSC for the three services. Thus, in the description of DSC, the general averages of each hospital compared to B-NWI-R were restated, which is in line with the "technique" known as a joint display in mixed studies, which means the joint illustrative presentation of quantitative and qualitative results. ${ }^{19}$

All ethical requirements involving human research have been respected. Therefore, the research project was submitted and approved by an institutional ethics committee and is accredited nationally by the CAAE protocol: 58571216.4.0000.0104.

\section{RESULTS}

The first phase (QUAN) of the study involved the participation of $226(100 \%)$ full-time nursing workers in the ICUs of the three hospitals. The distribution of participants among the research sites was: $\mathrm{AH}(\mathrm{n}=82 ; 36.2 \%)$; $\mathrm{HB}(\mathrm{n}=59,26.2 \%)$; and $\mathrm{HC}(\mathrm{n}=85,37.6 \%)$. Of the total, there were $56(24.8 \%)$ nurses and $170(75.2 \%)$ mid-level professionals. Of these, five were nursing assistants.

The highest proportion ( $n=124,55.2 \%$ ) of the participants were married, followed by unmarried ( $n=67,29.7 \%$ ), divorced ( $n$ $=28,12.5 \%$ ) and widowed $2.6 \%$ ). One participant did not declare marital status. Also, from the total, those who had children $(\mathrm{n}=$ $147 ; 65.3 \%)$ prevailed over those who did not $(n=78 ; 34.7 \%)$, and again one did not state whether they had children.

The mean age of the participants in each hospital was: $\mathrm{HA}=$ $36( \pm 8.6) ; \mathrm{HB}=30( \pm 8.4) \mathrm{e} ; \mathrm{HC}=39( \pm 8)$. The mean values of time in the ICU, in years, were: $6.3( \pm 4.7) ; 3.4( \pm 3.7)$ e; $7.4( \pm 5.4)$.

On the appreciation of the work environment perceived by the nursing team, Table 1 illustrates the descriptive findings, in addition to the result of the reliability test of the B-NWI-R scale and its subscales, relating them according to each hospital.

Table 2 shows the comparison of the working environment domains compared between the Accredited hospital $(\mathrm{AH})$ and the non-certified private hospital (HB).

Table 3 shows the comparison similar to the previous one; however, the "Accreditation" factor is contrasted with the perception about the working environment of the professionals crowded in the non-certified public hospital.

Table 4 presents data from the comparative analysis of the three groups. That is, accredited hospital $(\mathrm{AH})$, private noncertified (HB) and public without certification (HC).

The qualitative step of the sequential explanatory study had 39 interviews $(\mathrm{AH}=14, \mathrm{HB}=10 ; \mathrm{HC}=15)$ performed with professionals who participated in the first phase (QUAN). Chart 1 summarizes the DSC listed in each hospital, respecting the B-NWI-R domain approach in first-stage sequencing (QUAN) of the mixed study.

Table 1. Descriptive data on the perception of the work environment by the nursing team and reliability test of the Brazilian version of the Nursing Work Index Revised (B-NWI-R) scale, by hospital ( $n=226)$. Paraná, Brazil, 2017.

\begin{tabular}{|c|c|c|c|c|c|c|}
\hline Hospital & & Minimum & Maximum & Average & DP & Reliability* \\
\hline \multirow{5}{*}{ A } & Autonomy & 1 & 4 & 2.04 & 0.628 & 0.663 \\
\hline & Control over the environment & 1 & 4 & 2.05 & 0.570 & 0.691 \\
\hline & Physician-nurse relationship & & & & & \\
\hline & Organizational Support & 1 & 4 & 2.05 & 0.538 & 0.781 \\
\hline & General & 1 & 4 & 2.01 & 0.539 & 0.860 \\
\hline \multirow{5}{*}{ B } & Autonomy & 1 & 4 & 2.10 & 0.548 & 0.618 \\
\hline & Control over the environment & 1 & 4 & 2.12 & 0.581 & 0.751 \\
\hline & Physician-nurse relationship & & & & & \\
\hline & Organizational Support & 1 & 4 & 2.10 & 0.505 & 0.786 \\
\hline & General & 1 & 4 & 2.07 & 0.497 & 0.858 \\
\hline \multirow{6}{*}{ C } & Autonomy & 1 & 3 & 2.03 & 0.492 & 0.569 \\
\hline & Control over the environment & 1 & 3 & 2.07 & 0.503 & 0.673 \\
\hline & Physician-nurse relationship & & & & & \\
\hline & Organizational Support & 1 & 3 & 2.08 & 0.454 & 0.718 \\
\hline & General & 1 & 3 & 2.04 & 0.446 & 0.824 \\
\hline & B-NWI-R Geral & 1 & 4 & 2.04 & 0.492 & 0.846 \\
\hline
\end{tabular}

* Measured by Cronbach Alpha. 
Table 2. Comparison of perceived work environment domains among nursing professionals from a hospital accredited by Accreditation $(\mathrm{AH})$ and non-certified private hospital $(\mathrm{HB}) .(\mathrm{n}=141)$. Paraná, Brasil, 2017.

\begin{tabular}{|c|c|c|c|c|c|}
\hline & Hospital & Average & DP & IC 95\%* & $p$-value** \\
\hline \multirow{2}{*}{ Autonomy } & $A$ & 2.04 & 0.628 & \multirow{2}{*}[-0.268-0.151]{} & \multirow{2}{*}{0.494} \\
\hline & B & 2.10 & 0.548 & & \\
\hline \multirow{2}{*}{ Control over the environment } & A & 2.05 & 0.570 & \multirow{2}{*}[-0.271-0.121]{} & \multirow{2}{*}{0.462} \\
\hline & B & 2.12 & 0.581 & & \\
\hline \multirow{2}{*}{ Physician-nurse relationship } & A & 1.88 & 0.729 & \multirow{2}{*}[-0.423-0.068]{} & \multirow{2}{*}{0.162} \\
\hline & B & 2.06 & 0.723 & & \\
\hline \multirow{2}{*}{ Organizational Support } & A & 2.05 & 0.538 & \multirow{2}{*}[-0.229-0.137]{} & \multirow{2}{*}{0.598} \\
\hline & B & 2.10 & 0.505 & & \\
\hline \multirow{2}{*}{ Total } & A & 2.01 & 0.539 & \multirow{2}{*}[-0.240-0.129]{} & \multirow{2}{*}{0.493} \\
\hline & B & 2.07 & 0.497 & & \\
\hline
\end{tabular}

* Confidence interval between differences; ${ }^{* *}$ Mann-Whitney non-parametric test.

Table 3. Comparison of perceived work environment domains among nursing professionals from a hospital accredited by Accreditation (AH) and non-certified public hospital (HC). ( $n=167)$. Paraná, Brazil, 2017.

\begin{tabular}{|c|c|c|c|c|c|}
\hline & Hospital & Average & DP & IC 95\%* & $p$-value** \\
\hline \multirow{2}{*}{ Autonomy } & A & 2.04 & 0.628 & \multirow{2}{*}[-0.160-0.194]{} & \multirow{2}{*}{0.852} \\
\hline & C & 2.03 & 0.492 & & \\
\hline \multirow{2}{*}{ Control over the environment } & A & 2.05 & 0.570 & \multirow{2}{*}[-0.193-0.140]{} & \multirow{2}{*}{0.752} \\
\hline & C & 2.07 & 0.503 & & \\
\hline \multirow{2}{*}{ Physician-nurse relationship } & A & 1.88 & 0.729 & \multirow{2}{*}[-0.307-0.115]{} & \multirow{2}{*}{0.372} \\
\hline & C & 1.98 & 0.647 & & \\
\hline \multirow{2}{*}{ Organizational Support } & A & 2.05 & 0.538 & \multirow{2}{*}[-0.183-0.131]{} & \multirow{2}{*}{0.745} \\
\hline & C & 2.08 & 0.454 & & \\
\hline \multirow{2}{*}{ Total } & A & 2.01 & 0.539 & \multirow{2}{*}[-0.184-0.130]{} & \multirow{2}{*}{0.736} \\
\hline & C & 2.04 & 0.446 & & \\
\hline
\end{tabular}

* Confidence interval between differences; ${ }^{* *}$ Mann-Whitney non-parametric test.

\section{DISCUSSION}

Nursing professionals young adults sample ratified, by the majority of subscales by hospitals and in general, the reliability of the use of B-NWI-R. Another aspect that can leverage the reliable position of responses is the high performance time in all hospitals. In other words, the workers who know the labor dynamics of their service, in fact, condensed reliable perception, measurable, via an applied instrument, that is, the B-NWI-R measured what was proposed.

The small amount of nursing assistants among the participants is a positive result because, according to current regulations for the operation of the ICU, it is possible to note the mention of the nursing technician when referring to nursing professionals. ${ }^{20}$ There is a possibility that nursing assistants have been trained throughout the professional career; however, the permanence of this category, in critical areas such as ICU, is questionable.

Concerning the perception about the work environment, the professionals working in the three services did not have contrasting differences measured by scores. This is reinforced by the critical observation of DSCs, which, in general, presented similar "content". Likewise, in all descriptive quantitative analyzes, we can see the tendency of professionals to assign a positive evaluation to the work environment. In this respect, the accredited hospital obtained a better score and the private hospital not certified, the worst.

It should be noted that in the three groups of workers the autonomy dimension evaluated by the B-NWI-R did not reach the reliability attributed to the scale responses. Possibly, this occurred because nurses and mid-level professionals may have interpreted the evaluative domain and its items differently - since 
Table 4. Comparison of the domains of the work environment perceived by the three groups of nursing professionals. ( $n=226)$. Paraná, Brazil, 2017.

\begin{tabular}{cccccc}
\hline & Hospital & Average & DP & IC 95\%* & $p$-value** \\
\hline \multirow{3}{*}{ Autonomy } & A & 2.04 & 0.628 & {$[1.90-2.19]$} & \\
& B & 2.10 & 0.548 & {$[1.95-2.25]$} & 0.790 \\
Control over the environment & C & 2.03 & 0.492 & {$[1.92-2.13]$} & \\
& A & 2.05 & 0.570 & {$[1.92-2.18]$} & \\
Physician-nurse relationship & B & 2.12 & 0.581 & {$[1.97-2.28]$} & 0.685 \\
& C & 2.07 & 0.503 & {$[1.96-2.19]$} & \\
Organizational Support & A & 1.88 & 0.729 & {$[1.72-2.05]$} & \\
& B & 2.06 & 0.723 & {$[1.87-2.25]$} & 0.332 \\
& C & 1.98 & 0.647 & {$[1.84-2.12]$} & \\
Total & A & 2.05 & 0.538 & {$[1.93-2.17]$} & \\
& B & 2.10 & 0.505 & {$[1.96-2.23]$} & 0.750 \\
& C & 2.08 & 0.454 & {$[1.98-2.18]$} & \\
& A & 2.01 & 0.539 & {$[1.89-2.14]$} & \\
& B & 2.07 & 0.497 & {$[1.93-2.20]$} & 0.632 \\
\hline
\end{tabular}

* Confidence interval between differences; ${ }^{* *}$ Non-parametric Kruskal-Wallis test.

the professional definition of each working class is different - and thus demands an unequal distribution of power, which may be influenced by the hierarchical division of Brazilian nursing.

The averages of the autonomy domain attributed to the employees of the hospital certified by Acreditação and the non-certified public hospital were similar to that of another study developed with nurses working in the emergency unit of a public university hospital in the south of Brazil, determined in 2,05, and a study conducted with 162 nurses from the city of São Paulo, identified in 2,3. ${ }^{21,9}$ The same average values were worse than a survey with a sample of 114 nursing professionals from the interior of São Paulo, who obtained an average value of 1,936, and in a study of 202 professionals from the Magnet ${ }^{\circledR}$ organizations in the United States, who obtained an average value of 1.35 for autonomy in the work environment.. ${ }^{22}$ All the studies cited used B-NWI-R as a means of measuring the phenomenon.

Among the nurses, it is highlighted that the leadership, whose competence is required and expected for this category, tends to be defining the work environment that the team inserts. ${ }^{23}$ In addition to this, governance - management practice involving the nurse's leadership exercise - has already been scored as positive when establishing professional environments favorable to professional performance, as governance falls under rational strategies of relational and instrumental management that are inevitably immersed in the work environment. ${ }^{24}$ Although this relationship with the literature is important, it is worth mentioning that the study was developed with the participation of the entire nursing team in the ICUs of the three hospitals, and not only with nurses, as seen in another recent study. ${ }^{25}$

The previous interpretation reinforces the worst perceived autonomy among the professionals of the non-certified private hospital, as well as the general measurement of the work environment by the subjects of this place. To a certain extent, this finding refers to a favorable interpretation of Accreditation about the work environment of the nursing team when compared to private hospitals, since the positive difference between the certified hospital was greater in the comparison of data between institutions of this same type of care, than when comparing the private organization accredited to the public not certified.

Another aspect that reaffirms the positive perspective of Acreditation as a mediator of the environment conducive to nursing practice is the fact mentioned in the literature, which points out nurses as a driver of improvements in the work process in certified hospitals, since their performance, based on articulated care knowledge with the management, is a protagonist in the challenging and continuous work of Accreditation. ${ }^{26}$ In contrast, the preponderant data of this mixed research, which are numerical, associated to the literature, to the example of a study developed in the interior of the state of São Paulo, also using the B-NWI-R, accuse that Accreditation does not interfere in the practice environment of nursing. ${ }^{13}$

Accreditation may interfere in the control of nurses' practice and autonomy, but this was not observed in this research, in its objective dimension (statistical difference between institutions), even though in the subjective it was verified the "good" control 
Chart 1. Discourses of the Collective Subject (DSC) and general averages related to the work environment and its domains, perceived by nursing professionals, by hospital. Paraná, Brazil, 2017.

\begin{tabular}{|c|c|c|}
\hline $\mathrm{AH}(2,01)$ & HB $(2,07)$ & HC $(2,04)$ \\
\hline $\begin{array}{l}\text { The nurse is in direct supervision of } \\
\text { the team; then, with regard to patient } \\
\text { care, together with the doctor, are } \\
\text { the highest authorities here. The } \\
\text { nursing technician cannot exchange } \\
\text { dressing for central venous catheter. } \\
\text { The nurse has autonomy. So much } \\
\text { do we need to talk to her. [superviser } \\
\text { nurse]to then move forward. There is } \\
\text { control, even in caring. But you have } \\
\text { to impose yourself and show that you } \\
\text { have knowledge. I make decisions for } \\
\text { the knowledge I have. There are things } \\
\text { that are discussed and others that are } \\
\text { decided, and we know it later. Also, } \\
\text { physicians that are here have a little } \\
\text { more open minded. With the callers } \\
\text { the dialogue is open, it is possible to } \\
\text { have direct contact. In four years of } \\
\text { work, I never have a problem. It could } \\
\text { improve, but we get along with the } \\
\text { doctors. With the management we are } \\
\text { free to speak, to expose. The manager } \\
\text { is always available. Every time I needed } \\
\text { it, I was very well received. I think the } \\
\text { relationship with management is good. } \\
\text { For example, the head of the doctors, } \\
\text { she is sensational. As I said, we suffer a } \\
\text { lot from management, there is a lot of } \\
\text { pressure. }\end{array}$ & $\begin{array}{l}\text { At least in the morning, we can solve } \\
\text { everything calmly; but in the afternoon } \\
\text { it is not the same way. I think it does } \\
\text { not have autonomy, I think nursing is } \\
\text { a doctor's doormat. But I've worked } \\
\text { in other hospitals that have a doctor } \\
\text { who chooses which patient is going to } \\
\text { stay with the nursing technician. Not } \\
\text { here. On the contrary, they [doctors] } \\
\text { give full support to the people. I quietly } \\
\text { discuss with the doctor about the } \\
\text { medication that I think could help the } \\
\text { patient. I think the nurse has a good } \\
\text { control, that part is quieter. The nurses } \\
\text { question the doctors about the bladder } \\
\text { catheters and, in many cases, they are } \\
\text { withdrawn by the nurse's decision. } \\
\text { With the doctors here our relationship } \\
\text { is quiet. I've never had any problems, } \\
\text { always have a good conversation, a } \\
\text { good understanding. With the boss, } \\
\text { we have a good relationship. It is more } \\
\text { open to negotiation. You have respect. } \\
\text { But sometimes we feel very charged, } \\
\text { something that does not happen in } \\
\text { other shifts. I get along very well with } \\
\text { the management. However, it could be } \\
\text { more flexible, really demanding what is } \\
\text { needed. }\end{array}$ & $\begin{array}{l}\text { We have a bit of autonomy, even as } \\
\text { nursing technician. Nurses listen a } \\
\text { lot, maybe for experience. However, } \\
\text { there are still many things that it is the } \\
\text { doctor who solves. I think nursing has } \\
\text { control. We have here in the hospital } \\
\text { the Systematization of Nursing Care. } \\
\text { This gave autonomy for the nurse to } \\
\text { prescribe and also for the technician } \\
\text { to perform. Often it depends a lot on } \\
\text { the nurse, right? Because he makes a } \\
\text { point of his autonomy in the sector. The } \\
\text { nurse may make the decision to pass } \\
\text { a catheter, for example, and usually in } \\
\text { other institutions, the nurse will only do } \\
\text { this if the doctor prescribes. There's a } \\
\text { doctor who does not like you to speak, } \\
\text { give an opinion. But in general, they } \\
\text { are all very accessible. I realize a great } \\
\text { relationship with the doctors. First, } \\
\text { because we have been living together } \\
\text { for a long time. Of course, there are } \\
\text { doctors and doctors, but what stands } \\
\text { out is this good relationship. We are } \\
\text { wide open. When we come with a } \\
\text { proposal, it is very accessible. The } \\
\text { manager is an excellent professional, } \\
\text { always interacting, making meetings, } \\
\text { etc. If she can help, she helps. }\end{array}$ \\
\hline
\end{tabular}

over the nurse's practice in $\mathrm{AH}$. It is believed that this reality reinforces studying mixed method as innovator, and, mainly, embracing interpretation of scientific results.

It is prudent to reinforce that no inferential statistical analysis has resulted in significance, either in the comparisons made between pairs of professional groups, as well as in the joint assessment of the working environment of the three groups of workers. This data is in line with the results of a research that pointed out that it did not identify significant differences in the appreciation of the nursing work environment of public hospitals, even one of them having the certification seal..$^{13}$ Another study developed in the south of Brazil, with nurses in management and care positions, also did not point out statistical differences in the perception of working environment in the comparison between groups, ${ }^{25}$ fact that, despite going beyond Accreditation as a measurement factor, it makes an interesting comparison of the findings.
Summing up the literature prior to the global findings of this research - that is, considering its qualitative dimension as contribution to the measurements used -, it is inferred that, in the bulge of the investigated institutions, the Acreditation did not interfere in the work environment perceived by the nursing team.

It is agreed with prior research that the appreciation of the work environment is most likely to be interfered with in addition to the Accreditation quality seal..$^{13}$ In this perspective, it is valid to say that, although the work environment is a possible measurement factor, to the viability example by B-NWI-R, this is a subjective aspect that may have deep dimensions to be considered in professional perception, such as satisfaction with work, life experiences, and even interpersonal relationships in the work environment. Despite this, the sequenced qualitative dimension of this research reinforced the equitable content in the view of the nursing professionals about their work environment. 
Refuting the subjective interpretation of the work environment, Acreditação is a management system that relies on systemic organizational evaluation, based on standards listed in the logic of its integral care, that is, "all or nothing". ${ }^{11}$ In this perspective, this study suggests to the Accreditation management entities, as well as to the accredited accrediting institutions, that include in a more forceful way the appreciation of labor relations in the health environment, because there is evidence that the work environment is related intimately with the qualified and safe care. ${ }^{7,5,8}$

In health work relationships, overcoming "mere" tasks and providing assistance may not be sufficient for good working relationships that culminate in ethical and teamwork. ${ }^{27}$ In this sense, the findings related to work relationships between physicians and nursing professionals were another positive facet that surrounded the work environment perceived by the teams of the three hospitals, with quantitative emphasis (in descriptive terms) discrete for the organization certified by Accreditation.

The relationship between the nursing and medical teams certainly intervenes in the environment of professional practice, especially in the ICU, where the doctors are, together with the nursing team, in daily shifts. In addition, organizational support, which also unfolds in working relationships between management and subordinates, was also more positive among the group of professionals of this hospital.

In Accreditation at the level of excellence, as in the case of $\mathrm{AH}$, it is required its proof of managerial maturity, mediated by rational strategies strictly aligned with the continuously evaluated results. Therefore, in the cyclical and systematic management, towards quality in the various organizational spheres. ${ }^{11,10}$

Cyclical management procedure referred to can be facilitated in terms of the positive organizational support to the practice of the workers in the care environment; that is, in the support of managers to those responsible for direct care, whose fact was observed in particular in the DSC of $\mathrm{AH}$ and $\mathrm{HC}$.

It is considered that the favorable organizational support, perceived by the professionals in the accredited hospital, is a factor that, indirectly, can be translated as managerial commitment to the subordinates. This, despite reaffirming Accreditation as a management system based on strategic ability, includes not only the rational use of management tools for the improvement of care, but also the development of relational skills for managerial action. ${ }^{10}$

As limitations of this research, it is pointed out the impossibility of generalizing its results and the non inclusion of different levels of Accreditation certification in the comparisons. In spite of this, the study is innovative, both because it deals with the still vague knowledge about Accreditation interferences in health work, but also - and perhaps mainly - when approaching the theme in a global perspective, by the use of mixed methods.

\section{CONCLUSION}

Groups of nursing workers in the hospitals surveyed favorably perceive their professional practice environments. Even with more positive evaluations, in the quantitative dimension of the study, there was no significant statistical difference in the positioning of the Accreditation factor on the work environment, either in the comparisons between pairs, as well as in the evaluation of the three condensed groups. In addition, the qualitative sequencing of the mixed explanatory study ratified equity among the three sites in the perception about the nursing work environment.

It is concluded that the Accreditation did not significantly interfere in the nursing workers' perception about your work environment. Despite this, the results obtained through the mixed approach - whose main purpose is to achieve higher levels of evidence - suggest that the practice environment in the certified service, although not significantly different, was better.

\section{FINANCING}

Doctorate scholarship granted by the Coordination of Improvement of Higher Level Personnel (CAPES) to the research's first author, in the period May-July 2017.

\section{REFERENCES}

1. Marcelino CF, Alves DFS, Gasparino RC, Guirardello EB. Validation of the nursing index-revised among nursing aides and technicians. Acta Paul Enferm [Internet]. 2014 Aug; [cited 2017 Apr 23]; 27(4):305-10. Available from: http://www.scielo.br/pdf/ape/v27n4/en_1982-0194ape-027-004-0305.pdf. DOI: 10.1590/1982-0194201400052

2. Oliveira EM, Barbosa RL, Andolhe R, Eiras FR, Padilha KG. Nursing practice environment and work satisfaction in critical units. Rev Bras Enferm [Internet]. 2017 Jan/Feb; [cited 2017 Apr 23]; 70(1):73-80. Available from: http://www.scielo.br/pdf/reben/v70n1/en_0034-7167reben-70-01-0079.pdf. DOI: 10.1590/0034-7167-2016-0211

3. Rochefort CM, Clarke SP. Nurses' work environments, care rationing, job outcomes, and quality of care on neonatal units. J Adv Nurs [Internet] 2010 Oct; [cited 2017 Apr 22]; 66(10):2213-24. Available from: http:// onlinelibrary.wiley.com/doi/10.1111/j.1365-2648.2010.05376.x/pdf. DOI: 10.1111/j.1365-2648.2010.05376.x

4. Ma C, Olds DM, Dunton NE. Nurse work environment and quality of care by unit types: A cross-sectional study. Int J Nurs Stud [Internet] 2015 Oct; [cited 2018 Feb 10]; 52(10):1565-72. Available from https://www.ncbi.nlm.nih.gov/pubmed/26166148. DOI: 10.1016/j. ijnurstu.2015.05.011

5. Alves DFSA, Guirardello EB. Nursing work environment, patient safety and quality of care in pediatric hospital. Rev Gaúcha Enferm [Internet]. 2016 Jun; [cited 2017 Apr 20]; 37(2):e58817. Available from: http://www.scielo.br/pdf/rgenf/v37n2/en_01026933-rgenf-1983-144720160258817.pdf. DOI: 10.1590/19831447.2016.02.58817

6. Guirardello EB. Impact of critical care environment on burnout, perceived quality of care and safety attitude of the nursing team. Rev Lat Am Enferm [Internet]. 2017 Jun; [cited 2017 Apr 23]; 25:e2884. Available from: http://www.scielo.br/scielo.php?pid=S0104 11692017000100338\&script=sci_arttext\&tlng=pt. DOI: 10.1590/15188345.1472.2884 
7. Institute of Medicina (US). Keeping Patients Safe: Transforming the Work Environment of Nurses. Washington (DC): National Academies Press; 2004.

8. Olds DM, Aiken LH, Cimiotti JP, Lake ET. Association of nurse work environment and safety climate on patient mortality: A cross-sectional study. Int J Nurs Stud [Internet]. 2017 Sep; [cited 2017 Apr 20]; 74:15561. Available from: http://www.journalofnursingstudies.com/article/ S0020-7489(17)30129-3/pdf. DOI: 10.1016/j.jinurstu.2017.06.004

9. Maurício LFS, Okuno MFP, Campanharo CRV, Lopes MCBT, Belasco AGS, Batista REA. Professional nursing practice in critical units: assessment of work environment characteristics. Rev Latino Am Enferm. [Internet]. 2017; [cited 2017 Apr 21]; 25:e2854. Available from: http://www.scielo.br/pdf/rlae/v25/0104-1169-rlae-25-e2854.pdf. DOI: $10.1590 / 1518-8345.1424 .2854$

10. Oliveira JLC, Matsuda LM. Benefits and difficulties in the implementation of hospital accreditation: The voice of quality managers. Esc Anna Nery [Internet]. $2016 \mathrm{Jan} / \mathrm{Mar}$; [cited 2017 Apr 20]; 20(1):63-9. Available from: http://www.scielo.br/pdf/ean/v20n1/en_1414-8145-ean-20-01-0063.pdf. DOI: $10.5935 / 1414-8145.20160009$

11. Organização Nacional de Acreditação (BR). Manual das organizações prestadoras de serviços de saúde. Brasília (DF): Organização Nacional de Acreditação; 2014.

12. Oliveira JLC, Matsuda LM. Disqualification of certification by hospital accreditation: perceptions of professional staff. Texto Contexto Enferm [Internet]. 2016 Apr; [cited 2017 Apr 20]; 25(1):e4430014. Available from: http://www.scielo.br/pdf/tce/v25n1/0104-0707-tce-25-01-4430014.pdf. DOI: 10.1590/0104-07072016004430014

13. Oliveira PB, Spiri WC, Acqua MQD, Mondini CCSD. Comparasion between the accredited and non-accredited public hospital working environments. Acta Paul Enferm [Internet] 2016 Jan/Fev; [cited 2017 Apr 21]; 29(1):53-9. Available from: http://www.scielo.br/pdf/ape/ v29n1/en 1982-0194-ape-29-01-0053.pdf. DOI: 10.1590/19820194201600008

14. Fetters MD, Curry LA, Creswell JW. Achieving Integration in Mixed Methods Designs-Principles and Practices. Health Serv Res [Internet]. 2013 Oct; [cited 2017 Apr 21]; 48(6 Pt 2):2134-56. Available from: https://www.ncbi.nlm.nih.gov/pubmed/24279835. DOI: 10.1111/14756773.12117

15. Paranhos R, Figueiredo Filho DB, Rocha EC, Silva Júnior JA, Freitas D. Uma introdução aos métodos mistos. Sociologias (Porto Alegre) [Internet]. 2016 May/Aug; [cited 2017 Apr 20]; 18(42):384-411. Available from: http://www.scielo.br/pdf/soc/v18n42/1517-4522-soc-18-42-00384. pdf. DOI: 10.1590/15174522-01800422

16. Gasparino RC, Guirardello EB. Translation and cross-cultural adaptation of the "nursing work index" - revised" into Brazilian portuguese. Acta Paul Enferm [Internet]. 2009; [cited 2017 Apr 20];22(3):281-7. Available from: http://www.scielo.br/pdf/ape/v22n3/en_a07v22n3.pdf. DOI: 10.1590/ S0103-21002009000300007

17. Tavakol M, Dennick R. Making sense of Cronbach's alpha. Int J Med Educ [Internet]. 2011; [cited 2017 Apr 21];2:53-5. Available from: https:// www.ncbi.nlm.nih.gov/pmc/articles/PMC4205511/pdf/ijme-2-53.pdf. DOI: 10.5116/ijme.4dfb.8dfd
18. Lefevre F, Lefevre AMC, Marques MCC. Discourse of the collective subject, complexity and self-organization. Ciênc Saúde Coletiva. [Internet].2009 Jul/ Aug; [cited 2017 Apr 20]; 14(4):1193-204. Available from: http://www.scielo.br/scielo.php?script=sci_arttext\&pid=S1413-81232009000400025. DOI: 10.1590/S1413-81232009000400025

19. Guetterman TC, Fetters MD, Creswell JW. Integrating quantitative and qualitative results in health science mixed methods research through joint displays. Ann Fam Med [Internet]. 2015 Nov; [cited 2017 Apr 20]; 13(6):554-61. Available from: http://www.annfammed.org/ content/13/6/554.long. DOI: 10.1370/afm.1865

20. Ministério da Saúde (BR). Agência Nacional de Vigilância Sanitária. Resolução - RDC № 26 de 11 de maio de 2012. Altera a Resolução RDC n. ${ }^{\circ} 07$, de 24 de fevereiro de 2010 , que dispõe sobre os requisitos mínimos para funcionamento de unidades de terapia intensiva e dá outras providências. Brasília (DF): Ministério da Saúde; 2012. [Internet] [cited 2017 Apr 24] Available from: http://bvsms.saude.gov.br/bvs/ saudelegis/anvisa/2012/rdc0026_11_05_2012.html

21. Santos JLG, Menegon FHA, De Pin SB, Erdmann AL, Oliveira RJT, Costa IAP. The nurse's work environment in a hospital emergency service. Rev Rene [Internet]. 2017 Mar/Abr; [cited 2017 Apr 20]; 18(2):195-203. Available from: http://www.periodicos.ufc.br/rene/article/view/19246. DOI: 10.15253/2175-6783.2017000200008

22. Clavelle JT, O'Grady TP, Drenkard K. Structural empowerment and the nursing practice environment in Magnet $\AA$ organizations. J Nurs Adm [Internet]. $2013 \mathrm{Nov}$; [cited 2018 Feb 10]; 43(11):566-73. Available from: https://www.ncbi.nlm.nih.gov/pubmed/24153197. DOI: 10.1097/01. NNA.0000434512.81997.3f

23. Balsanelli AP, Cunha ICKO. The work environment and leadership in nursing: an integrative review. Rev Esc Enferm USP [Internet]. 2014 Aug [cited 2017 Apr 20]; 48(5):934-40. Available from: http://www.scielo.br/ pdf/reeusp/v48n5/0080-6234-reeusp-48-05-938.pdf. DOI: 10.1590/ S0080-623420140000500022

24. Santos JLG, Erdmann AL. Governance of professional nursing practice in a hospital setting: a mixed methods study. Rev Lat Am Enferm [Internet] 2015 Nov/Dec; [cited 2017 Apr 20]; 23(6):1024-32. Available from: http:// www.scielo.br/pdf/rlae/v23n6/0104-1169-rlae-23-06-01024.pdf. DOI: 10.1590/S0080-623420140000500022

25. Santos JLG, Erdmann AL, Peiter CC, Alves MP, Lima SBS, Backes VMS. Comparison between the working environment of nurse managers and nursing assistants in the hospital context. Rev Esc Enferm USP [Internet]. 2017 Mar; [cited 2018 Mar 8]; 51:e03300. Available from http://www.scielo.br/pdf/reeusp/v51/1980-220X-reeusp-S1980 220X2017017103300.pdf. DOI: 10.1590/S1980-220X2017017103300

26. Oliveira JLC, Hayakawa LY, Versa GLGS, Padilha EF, Marcon SS Matsuda LM. Nurses' performance in the accreditation process: perceptions of the multiprofissional team from the hospital. Rev Baiana Enferm [Internet]. 2017; [cited 2017 Apr 20]; 31(2):e17394. Available from: https://portalseer.ufba.br/index.php/enfermagem/article/ viewFile/17394/14631. DOI: 10.18471/rbe.v31i2.17394

27. Silveira RS, Martins CR, Lunardi VL, Vargas MAO, Lunardi Filho DW Avila LI. The moral dimension of care in intensive therapy. Ciênc Cuid Saude. [Internet]. 2014 Apr/Jun; [cited 2017 Apr 21]; 13(2):327-34 Available from: http://periodicos.uem.br/ojs/index.php/CiencCuidSaude/ article/view/19235/pdf_170.DOI: 10.4025/cienccuidsaude.v13i2.19235

\footnotetext{
${ }^{\text {a }}$ Article extracted from the doctoral dissertation defended by the first author under the supervision of Dr. ${ }^{\text {a }}$ Laura Misue Matsuda. "Influence of hospital accreditation in the nursing team work: a mixed method study", Graduate Program in Nursing - State university of Maringá. 2017.
} 